\title{
Juridical (Legal) Study of Compensation of Delayed Payment (Remittance) of Cash
}

\author{
Alireza Amini ${ }^{1}$ \& Reza bakhtiyari ${ }^{1}$ \\ ${ }^{1}$ Faculty of Theology and Philosophy, Islamic Azad University, Science and Research, Tehran, Iran \\ Correspondence: Alireza Amini, Faculty of Theology and Philosophy, Islamic Azad University, Science and \\ Research, Tehran, Iran. E-mail: a-amini@srbiau.ac.ir
}

Received: July 4, 2016 Accepted: August 10, 2016 Online Published: August 30, 2016

doi:10.5539/jpl.v9n7p257 URL: http://dx.doi.org/10.5539/jpl.v9n7p257

\begin{abstract}
Compensation of delayed payment (remittance) is the harm caused by non-payment of debt (cash) in deadline to creditor which is one of the best examples of this issue in the banking. Receiving compensation for delayed payment (remittance), is a common and customary in the world and lack of it, strong enforcement to receive demands wouldn't be there from debtors but in Islamic jurisprudence receiving additive payment on the principle of debt has been considered as an example of usury, thus considering the importance of the debate, a more detailed explanation seem necessary in view of jurists and the question is posed what is the Shiite jurists' arguments on this?

Of achievements of this study which has been done descriptive-analytic is the examination of arguments of adherents of permissibility or impermissibility of receiving compensation for delayed payment to compel the debtor to pay of his/her debt.
\end{abstract}

Keywords: damage, delay, payment (remittance), cash, usury, condition

\section{Problem Statement}

The issue of compensation for delayed payment (remittance) has been posed under the general title of damage resulting from a breach of undertakings and it means the delay of time so that in custom (practice) passing time (deadline) taken into account delay, whether the deadline is stipulated in the contract or without specifying in custom (practice) for that act or transaction a deadline is considered. About payment (remittance) could be said that payment (remittance) subject sometimes is doing a work or delivery of goods and sometimes paying cash may also be due to the loan contract, sale, rental and like these. If the issue of payment (remittance) or obligation is cash, the compensation of delayed payment is used and if the issue of obligation is not cash, delay compensation of obligation is used. So we can say: compensation of delayed payment (remittance) is the harm caused by non-payment of debt (cash) in deadline has been entered to creditor. However it the "damage delay in payment (remittance)" can be interpreted as damages for failure to perform the obligation, because the mo'addi (person who should be paid) and owes under the contraction obligate to pay debt and if doesn't pay his/her debt on time, in fact, has not fulfilled his/her obligation.

The issue is of legal-jurisprudence issues which has been much attended and today debate about it has found so much importance and various positions have been taken by the legal authorities about it because on the one hand receiving compensation from such debtors is widespread and common in the world and the lack of it, there will be no sanction to get the demands from the debtors, on the other hand, there is the view that the religious teachings has prohibited the additive payment on the original debt. According to the necessity for compensation of entered damage and suspicion of being unlawful of receiving compensation of delayed payment (remittance) of cash and necessity of accordance of legal provisions with rules of sacred religion according to the fourth principle constitution of the Islamic Republic of Iran and explore as much about it as necessary.

\section{The Compensation of Delayed Payment (Remittance) of Cash}

One of the examples of failure to perform of obligation or delay in performing it is non-payment (remittance) of debt. Damage is the losses that entered to person. In terminology any aggrieved reduction in damaged person's property, is called damage (detriment). The compensation of delayed payment (remittance) is detriment that is entered to person due to refusal of the creditor to pay his/her financial losses at the deadline (Shahidi, works 
contracts and commitments, vol. 3, p. 68 and 84). About the validity or invalidity of compensation of delayed payment (remittance) several arguments and opinions have been put forward. Some people are adherents of permissibility and impermissibility that in following examine some arguments of each of them.

Reasons lack of permissibility to claim damages for delayed payment (remittance)

Most of Shiite (Emamieh) jurists believe lack of permissibility for delay penalty (Shahroudi, Ahle-beyt (inmate) jurisprudence Journal, Issue 2). As some have said clearly: the verse but Allah hath permitted trade and forbidden usury "(Surah al-Baqarah, verse 275) about impermissibility of further (additive) receiving against delay in debt (Imam Khomeini, [Al-Bey] Vending, vol. 5, p. 527, Khoyee, Minhaj- al-Saaliheen, vol. 2, p. 48). According to this view, loan usury, is not specific to the debt caused by loan contraction, but involves the debt caused by sale, credit, prebuy (salaf), usurpation, and ... as well, that in none of them the amount of debt because of passage of time and currency depreciation, does not change and the debtor only is guarantor of what which has received and pay more than of it is impermissible. Their reasons include;

1) Offset of currency depreciation is an example of usury and damages resulting from delay in the payment of debt, not a loss to be compensated. (Khoyee, Misbah al-Alfqaheh, vol. 3, p. 130).

2) Losses resulting from the currency depreciation is out of the will of the borrower and is not reason to compensate for such a loss, whether inflation is an external reality and not in the ability and authority of indebted (Yusufi, the Ahl-beyt (inmate) jurisprudence Journal, Issue 30).

3) The rate of increase or decrease in currency is unclear so that neither the creditors, not debtors at the time of conclusion of the contract do not aware of the amount and the size of increase or decrease in the value of money (currency) thus this type of contracts are affordable to ignorance and it is obvious that such contracts are prohibited due to null and ignorance of the parties (Yusufi, ibid., No. 30).

One of the contemporary jurists also said: In the cases that the amount of money or anything else given to others as interest-free repayment and its refund deadline is a few years later, can receive Just as it, whether it is goods ranging from cash, or other commodities that have intrinsic value, or the value which has currency valid, and if receive more than what they have paid, as inflation and devaluation of their money will be usury (Sobhani, Rahnamoon magazine, Issue 6).

According to opponents of claiming damages for delayed payment, the additive (further) raised in usury, including any kind of additive which its benefit is for the lender or third party, so if in the conclusion of the is provided debtor help a needy person or spend a money repairing the mosque or rent his/her house cheaper or sell less expensive, these cases are considered usury and not permitted (Khoyee, Minhaj-al-Saaliheen, vol. 2, p. 170).

One of the jurists in response to the fact that if under the loan contract, the condition of liability is caused by purchasing power has written: this condition is not correct and the same borrowed amount is guarantor and purchasing power does not affect on this issue (Imam Khomeini, Esteftaat, vol. 2, p. 291). About the seller in the sale of credit provide this condition if the customer doesn't pays the price in deadline, for every day or every month of delay, pay certain amount, it is answered that this requirement is not valid (Ibid., 102).

In these cases, it is believed that that the stipulation shouldn't be contrary to the Qur'an and Sunnah, so that such a condition is blunt and void and has no effect associated on it. In the credit sale, the price of transaction is determined and will be given to customer and the amount of debt does not change because of delay in the payment. One of the commentators of the Quran has written: In the days of ignorance usury loans was two types: sometimes the signing of the loan, was usury, and sometimes an additive was determining to extend of debt. That is the initial loan was not usury, but when deadline is arrived but person could not pay the debt, the creditor's condition was that the debtor would give him additive amount (Razi, MiftahAl-gheyb, vol. 9, p. 3, quoted by Rezaie, Journal of Islamic Economics, No. 6). One of the jurists in response to a question on bank penalties has written: the condition of additive, though as fees and other mentions in the question is usury and forbidden and penalty is also forbidden, but if indebted has been required (obligated) religious (legal) in the conditions of contract if the deadline is delayed, freely give a certain amount, is okay (Golpayegani, Majma-al-Masael [catechism assembly], vol. 2, p. 91).

\section{The Reasons for Permissibility to Claim Compensation for Delayed Payment}

About the claim of impermissibility of compensation of damages of delayed payment or delay penalty, some jurists consider the compensation of it necessary and have a variety of solutions to solve this problem, some of which we'll explain: 


\section{The Need to Compensate the Currency Devaluation}

Some believe that in the current situation value of money continually declining, so that today's money can no longer be regarded as money of some years ago, therefore, if the bank in the time of fulfilling its debt, pay the real value of the money that was already paid, will not be forbidden and usury (Shahid [martyr] Sadr, Public foundations for Bank in the Islamic complex, p. 19). In this theory, compensation of the currency devaluation is documented to purchasing power and transactional money value and have said: in the case of currency devaluation, the debtor must pay as much as purchasing power in receiving time, in order to be true, thus, what is the responsibility of the debtor, is the purchasing power and the money as property, not its nominal value. As is said about the payment of blood money and dowry the real value and power and updated of money should be paid to the devaluation is compensated. A number of contemporary jurists have ruled the need to compensate for currency depreciation, but for preventive or fatwa, compromises have been counted desirable or necessary (Bahjat, Question and Answer, Question 5690) as one of contemporary jurists has written: "If anyone borrow amount of gold and silver, or another parable things and the price goes down or is multiplied, so give what the same amount that has received is enough. However, if both are satisfied otherwise, there is no problem. And the condition of mentioned rule in paper money which due to its purchase power the transaction is done with it, and typically are on the gross rise and fall, is problematic and if the difference becomes significant, it is necessary compromise with each other "(Gerami, Tozih-al-masel [catechism], 2455 issue).

The Supreme Leader in response to a question of Chief Justice in Tehran dated 75/9/27 wrote: damage due to debt delay, if it is proven that is documented to delay payment is the liability of debtor and the judgment is not usury. (Information Newspaper, dated 1387/2/2 [in Persian date]). However in this answer, absolutely the compensation of delayed payment of cash is accepted and a decrease in purchasing power or stipulation or constraint and other details yet have not been pointed out. In short, proponents of this theory argue that annual money supply growth and inflation reduces the value of money (purchasing power or value of exchange). Lack of timely payment of debt, makes the real value of money decreases, thus, the debtor must pay the actual amount timely, however paying the debt timely can be more or less with the devaluation, but in the borrow, the lender with good intention seeking this benevolent contract, and ignores this decrease with satisfaction. But if in debt deadline, it is not attempted to paid, the vast majority of creditors in custom (practice) are not satisfied with these delays. It seems that this differentiation and promised to detail is desired, meaning in cases where the creditor is satisfied to stay loan in the hand of debtor with the knowledge of the decrease of monetary value, ruling of the need to compensate for currency depreciation is not good, but in cases where the debtor with in spite of financial ability and intentionally has negligence in paying debt and creditor is displeased due this, it can be based on the rule or the rule of no damage or causality, ruling to compensate the losses incurred by the creditor can be done. So that rationally and customary, paying a nominal amount of money by drastically reducing the administrative value of it is not considered as full paying of debt, but two points on the theory of the need to compensate for currency depreciation is required:

1) The amount of inflation in each society and our society is changing, the amount of inflation sometimes is inconsiderable or minimal and sometimes high or very high. However, if the amount of money in the bank which received as penalty for delay is consistent with the inflation that year, becomes consistent with this theory, but in practice banks receive and calculate the amount of fines six to ten percent more than loan interest and that does not have relationship with inflation.

2) According to jurisprudence the calculation of the currency devaluation based on inflation rate, in the debts is not approved because custom (practice) in low inflation consider the calculation of it additive and considers it tantamount to usury. That is custom in low inflation, considers the paid amount to the main debt. In addition, in the paying of debt of government and state institutions to employees and the public debt current devaluation could not be counted (Rezaei, Journal of Islamic Economics, No. 6).

\section{The Main Stipulation}

Another group of adherents of the necessity of compensation for delayed payment of cash have said: if the debtor in the form of stipulation is obligated if doesn't pay the debt timely, per year, twelve percent of the debt took on him, in this case, such a thing will not be subject to the traditions prohibition of usury and take its legitimacy and influence from reasons of the need to purchase and influence reasons of condition, not from debt which considered as usury As one of the jurists of the Guardian Council has said: the penalty for delay is not usury, but the bank says: in the beginning of month should pay your installments, not to pay penalty for a fee (payment) a month stay with you. Thus, delayed payment is not usury. Now that is not usury, if is stipulated under lending or conclusion has the rule of (Believers in their own terms), and the problem does not arise 
(Ayatollah Ali Rezvani, about Islamic banking, the Central Bank of Iran, 1372 [in Persian date]). In other words, such a group of jurists argue that usury is achieved if the lender with such a condition allows the borrower to delay in paying, but if the aim is obligate the debtor to pay off debts in deadline and the so-called penalty clause, it will be smooth. In fact, this fatwa considers a distinction between usury and penalty clause and says, the usury is an additive amount on the original debt, in exchange for granting a grace period, but in the mentioned assumption the lender wants nothing except original debt at maturity and the condition of amount in the delay premise, is only for obligation and compulsion to pay the loan on its maturity. Such as the fatwa has already been stated by one of the jurists: as the seller in the sale of credit could be provided to the buyer by the end of the year, monthly gift an amount freely to him, in the same way can be provided that in the case of delay in payment of the price and prescribed deadline, monthly give a certain amount to him (Shahid [Martyr Sadr], the Bank interest [usury]-free, p. 174).

About the second theory that correct the penalty of delayed payment due to the stipulation of the obligation to pay damages some points looks like ambiguous:

A: condition for the payment of fines, although is not valid in the contract, so that in accordance with Islamic traditions any condition that has been in favor of the lender is prohibited (HurrAmeli, Vsayelalshyiah, vol 18, $p$ 356 ) and even some jurists also do not consider this condition right (Imam Khomeini, Esteftaat, vol. 2, p. 102).

(B): in the interest [usury] banking, penalty for delayed payment with the debtor's obligation to pay damages is done in accordance the existing rules, so what difference does if it should be stipulated in the contract or the contract to be signed on it.

(C): the criterion of prohibition of usury (excessive borrowing on principle) still remains in this case, and it seems that this theory is a gimmick to escape from usury by changing the words to change reality. Evidence of this is that in the ignorance era one of the usuries was the compensation of delayed payment which are now established and common in non-Muslim communities.

\section{The Out Necessary Stipulation}

Another solution which has been provided to demand compensation of delayed payment of cash is the out necessary stipulation is. As one of the jurists in response to a question as it has written:

If the debtor in a religious (legal) manner, also out necessary stipulation is bound if to be delayed of due date, a specified amount freely give is not problematic (Golpayegani, [Majma-al-masael] catechism Assembly, vol. 2, p. 91). The indicating being free of additive amount, other jurists have identified and considered it permissible, provided in the text of the contract in exchange for granting it is not mentioned(Najafi, Javaher-al-Kalam, vol. 25, p. 7). The owner of Javahe-al-kalam about compensation of delayed payment has said:

If interest resulting from delayed payment is out necessary stipulation, as the mentioned contract based on dissolution of contracts is a contract separate from the loan contract, so if from this area an interest is reached, is not originated from the loan contract, but is made out of it, then the resulting benefit can't be taken into account as interest on the loan. Because the condition isn't interested but has become the condition of an act is out necessary stipulation. In other words, because the resulted benefit hasn't been originated from the debt contract then no offense is there. This means if know the conditions as stipulated not otherwise. If it is a part of the contract, the resulting benefit is derived from the contract, so it will be usury (interest), and if the condition (requirement) considered as an incidental condition, collateral, deadline, and mortgage, the interest on the debt will be canceled. Because such a condition only is restriction on the right to restitution of property and it compels the lender to get debt (Najafi, Javaher-al-Kalam, vol. 25, p. 5). In fact, in this view, the cause of compensation of delayed payment, is a separate obligation of the loan contract, which doesn't get its legitimacy and influence from the loan contract but the creditor with the necessary stipulation sells a commodity to the debtor and the debtor obligates in the case of failure to pay his/her debt in deadline, give an amount freely to the creditor. It is obvious that it could not be superfluous to the principle (interest or usury) and is not considered as taking another property viciously.

\section{Conclusion}

Most of Shiite (Emamieh) jurists believe lack of permissibility for delay penalty. As some have said explicitly: verse «Allah has permitted trading and forbidden usury», is about impermissibility of assistive amount in the case of delay in paying. According to this view, loan usury, is not specific to the debt caused by loan contraction, but involves the debt caused by sale, credit, prebuy (salaf), usurpation, and ... as well, that in none of them the amount of debt because of passage of time and currency depreciation, does not change and the debtor only is guarantor of what which has received and pay more than of it is impermissible. 
In the case of promise the impermissibility claim of damages of delayed payment or delay penalty, some jurists consider the compensation necessary and have a variety of solutions to solve these problems such as the need to compensate the currency devaluation in the main stipulation and out necessary stipulation and with the distinction between "penalty clause" and "interest [usury]" has legitimized insertion a clause in the contract in order obligation of debtor to respect the maturity and some have accepted claim for damages in case of delay in payment in the intense reduction in the value of money and ability of debtor to pay off debts established in maturity. It seems that a solution can be found that in addition to observance of common jurisprudence and legal (Juridical) provisions, the philosophy and wisdom of prohibition of usury, the wisdom of the lawfulness of transactions, the structure of Islamic financial markets and economic system of Islam and means supporting the vulnerable people and the Islamic government's responsibilities, including the responsibility for paying debts and helpless debtors... all together to be considered.

\section{References}

Ayatollah Ali Rezvani, about Islamic banking, the Central Bank of Iran, 1372[Persian date].

Behjat, Question and Answer, Question 5690.

Fakhr Razi, Miftah-Al-ghayb, vol. 9, p. 3, quoted by Rezaie, Journal of Islamic Economics, No. 6.

Gerami, catechism [Tozih-al-masael], 2455 issue.

Golpayegani, catechism assembly [Malm-al-masael].

HurrAmeli, Means Shiites(vasael-al-shiites).

Imam Khomeini, Esteftaat.

Imam Khomeini, Vending (Al-Bey'), vol. 5, p. 527, Khooyee, Minhaj-al-Saaliheen.

Information newspaper, dated in Persian $1387 / 2 / 2$.

Khooyee, (Menhaj-al-salehin) Platform righteous.

Khoyee, Misbah-al-faghahe.

Najafi, Javaher-al-Kalam.

Rezai, Journal of Islamic Economics, No. 6.

Shahid [Martyr] Sadr, the general basis of the bank in the Muslim compound.

Shahid [Martyr] Sadr, Bank interest[usury]-free.

Shahidi, Mehdi, works contracts and commitments, Tehran, Majd Publications, 2007, third edition, vol. 3, pp. 68 and 84 .

Shahroudi, the Ahl-albeyt ( inmate) Law Journal, Issue 2.

Sobhani, Rahnamoon magazine, Issue 6.

The Holy Quran.

Yousefi, Journal of the jurisprudence of the Ah-al-beyt, Issue 30.

\section{Copyrights}

Copyright for this article is retained by the author(s), with first publication rights granted to the journal.

This is an open-access article distributed under the terms and conditions of the Creative Commons Attribution license (http://creativecommons.org/licenses/by/4.0/). 